JURNAL ILMIAH KOMPUTER AKUNTANSI, Vol.13, No.1, Juli 2020, pp. 138 - 142

p-ISSN : 1979-116X (print)

e-ISSN : 2614-8870 (online)

http://journal.stekom.ac.id/index.php/kompak

\title{
Analisis Mahasiswa Kota Kendal Dalam Menggunakan E-Money dengan Metode TAM
}

\author{
Dendy Kurniawan ${ }^{1}$, Dwi Setiawan², Robby Andika Kusumajaya ${ }^{3}$ \\ ${ }^{1}$ Universitas Sains dan Teknologi Komputer \\ e-mail: dendy@stekom.ac.id \\ ${ }^{2}$ Universitas Sains dan Teknologi Komputer \\ e-mail: dwisetiawan@stekom.ac.id \\ ${ }^{3}$ Universitas Sains dan Teknologi Komputer \\ e-mail: robby@stekom.ac.id
}

\begin{tabular}{|c|c|}
\hline ARTICLE INFO & ABSTRACT \\
\hline $\begin{array}{l}\text { Article history: } \\
\text { Received } 30 \text { Mei } 2020 \\
\text { Received in revised form } 2 \text { Juni } 2020 \\
\text { Accepted } 10 \text { Juni } 2020 \\
\text { Available online } 12 \text { Juni } 2020\end{array}$ & $\begin{array}{l}\text { Tujuan Penelitian ini adalah untuk mengidentifikasi } \\
\text { faktor-faktor yang mempengaruhi minat masyarakat } \\
\text { menggunakan e-money dengan menggunakan } \\
\text { pendekatan deskriptif kuantitatif. Peneliti } \\
\text { menggunakan model technology acceptance model } \\
\text { (TAM) yang berfokus pada Kegunaan yang } \\
\text { Dirasakan, Kemudahan Penggunaan yang } \\
\text { Dirasakan, Risiko yang Dirasakan, dan terdapat } \\
\text { variabel tambahan yaitu Sikap Pelanggan dan niat } \\
\text { perilaku untuk menggunakan uang elektronik. } \\
\text { Pengujian data empiris dilakukan berdasarkan data } \\
\text { yang dikumpulkan dari } 84 \text { responden yang terdiri } \\
\text { dari mahasiswa yang berasal dari kota kendal dan } \\
\text { dari berbagai universitas, analisis reliabilitas, uji } \\
\text { validitas dan analisis regresi berganda untuk melihat } \\
\text { hubungan antara semua variabel. Hasil akhir } \\
\text { menunjukkan bahwa persepsi kegunaan, persepsi } \\
\text { kemudahan penggunaan, persepsi risiko, dan sikap } \\
\text { pelanggan berpengaruh positif signifikan terhadap } \\
\text { niat masyarakat menggunakan E-money. }\end{array}$ \\
\hline
\end{tabular}

Keywords: e-money; TAM

\section{Introduction}

Pesatnya Perkembangan teknologi telah mampu menginisiasi E-banking dan digitalisasi sistem pembayaran global [1]. Seiring berjalannya waktu sistem pembayaran terus berkembang dan ditemukan berbagai bentuk inovasi dalam hal pembayaran [2]. Indonesia merupakan salah satu negara yang telah diuntungkan oleh kemajuan teknologi dan inovasi sistem pembayaran yang dapat membawa Indonesia ke era digital dan informasi. Perkembangan teknologi yang terus mengalami penyempurnaan telah mampu memberikan inovasi fasilitas sistem pembayaran [3] yang mengubah uang tunai menjadi satu set kartu atau mobile (E-Money). Pembayaran elektronik secara substansial telah menggantikan pembayaran cek tetapi belum mengarah pada masyarakat tanpa uang tunai [4]. Pertumbuhan platform inovatif ini sangat tumbuh karena teknologi di pasar pada negara maju, tetapi akses terbatas di pasar negara berkembang. Namun, ketersediaan infrastruktur telekomunikasi telah mampu meningkatkan penggunaan E-Money secara luas [5]. 
Uang memiliki peran strategis dalam kegiatan ekonomi, sehingga uang terus mengalami perubahan proses moneter yang berdampak besar pada pertukaran, produksi dan kredit [6]. Hal ini sejalan dengan perkembangan yang terjadi, perdagangan elektronik yang dilakukan secara online, merangsang berbagai mekanisme pembayaran online. E-money sebagai metode pembayaran yang lebih efektif dan efisien tentunya memiliki banyak keunggulan yang ditawarkan kepada masyarakat jika dibandingkan dengan pembayaran tunai untuk melakukan pembayaran elektronik, mengirim pembayaran mobile, atau menggunakan uang elektronik [7]. Manfaat yang dirasakan, kemudahan penggunaan, risiko yang terkait dengan uang elektronik, dan manfaat yang dirasakan adalah nilai jual yang dapat ditawarkan kepada masyarakat untuk menggunakan uang elektronik sebagai metode pembayaran. Pemanfaatan teknologi merupakan komponen penting yang menentukan keberhasilan inovasi di masyarakat. Apa yang dipikirkan, dirasakan, dan dilakukan para inovator dan pengusaha dalam bentuk desain platform (e-money) tidak selalu selaras dan mampu memenuhi apa yang diinginkan pengguna [7]. Faktor-faktor yang menjadi aspek untuk menarik minat masyarakat dalam menggunakan uang elektronik dalam hal penggunaan yang efektif dan efisien belum tentu sama dengan yang dialami dan dirasakan oleh pengguna. Oleh karena itu, penelitian ini dilakukan untuk mengidentifikasi dan mengkaji faktorfaktor yang menarik minat masyarakat untuk menggunakan uang elektronik sebagai alat pembayaran di kota Mataram dengan menggunakan teori Technology Acceptance Model (TAM).

TAM merupakan teori yang dikembangkan oleh Fred \& Davis (1998) yang diadopsi dari beberapa model yang dibangun untuk menganalisis dan memahami faktor-faktor yang dimiliki, pengaruhnya terhadap penerimaan, penggunaan teknologi baru [8]. Jadi TAM merupakan model yang dapat digunakan sebagai konseptual dalam menggambarkan secara akurat penerimaan teknologi. Teori TAM merupakan model yang tangguh dalam berbagai kajian teknologi karena memberikan bukti yang substansial dan empiris. Perceived Usefulness (Kegunaan), Perceived Ease of Use (kemudahan), Perceived Risk (resiko), dan Perceived Use Intention (niat) adalah variabel yang digunakan dalam teori TAM ini [9]. Teori TAM merupakan model penerimaan teknologi (TAM) yang diterima secara luas sebagai model dalam menjelaskan fenomena adopsi teknologi baru [10].

\section{Research Method}

Penelitian ini menggunakan deskriptif kuantitatif sebagai desain dalam melakukan penelitian. Tujuan penggunaan desain deskriptif kuantitatif ini adalah untuk membahas penelitian yang dilakukan di lokasi penelitian, siapa, apa, di mana, kapan dan dimana peristiwa yang digunakan untuk objek penelitian ini terjadi [11]. Teknik pengambilan sampel menggunakan metode convenience sampling dan kemudian ditemukan 84 responden yang bersedia meluangkan waktunya untuk mengisi kuesioner. Kuesioner adalah kumpulan data yang diberikan kepada responden berupa pertanyaan-pertanyaan yang berkaitan dengan tema dalam penelitian sehingga responden merupakan sumber data utama yang digunakan dalam penelitian. Kuesioner sendiri merupakan salah satu metode yang sering digunakan untuk memperoleh data, baik penelitian di bidang bisnis dan manajemen, ilmu-ilmu sosial maupun ilmu-ilmu lainnya (Rowley, 2014). Kuesioner yang disebarkan dibuat dengan menggunakan skala Likert. Sehingga responden diharuskan mengisi salah satu dari lima skala likter yang disediakan; yaitu sangat tidak setuju, tidak setuju, netral, setuju, dan sangat setuju.

\section{Results and Analysis}

\subsection{Analisis Deskriptif Variabel Independen dan Dependen}

Tabel di bawah ini menunjukkan nilai analisis deskriptif pada variabel independen dan dependen. nilai rata-rata semua variabel berkisar antara 4,39 sampai 3,86 yang menunjukkan bahwa sebagian besar responden setuju dengan pernyataan pada masing-masing variabel. 
Tabel 1: Statistik deskriptif

\begin{tabular}{|l|c|c|c|c|c|c|c|c|}
\hline \multicolumn{1}{|c|}{ Indikator } & STS (1) & TS (2) & N (3) & S (4) & SS (5) & Jm1 & Skor & Rata-rata \\
\hline Kegunaan & 1 & 2 & 9 & 23 & 49 & 84 & 369 & 4,3928571 \\
\hline Kemudahan & 2 & 5 & 2 & 31 & 44 & 84 & 362 & 4,3095238 \\
\hline Resiko & 2 & 4 & 26 & 23 & 29 & 84 & 325 & 3,8690476 \\
\hline Niat & 0 & 2 & 15 & 27 & 40 & 84 & 357 & 4,25 \\
\hline
\end{tabular}

Sumber : data diolah 2020

\subsection{Uji Validitas}

Uji validitas digunakan untuk mengukur valid atau tidaknya suatu kuesioner. Suatu kuesioner dikatakan valid jika pernyataan pada kuesioner mampu untuk mengungkapkan sesuatu yang akan diukur oleh kuesioner tersebut.

Uji signifikan dilakukan dengan membandingkan nilai rhitung dengan rtabel. Pada kasus ini jumlah sampel $(n)=84$, nilai rtabel dihitung dengan rumus df (degree of freedom) $=n-2$ sehingga $\mathrm{df}=84-2=82$, maka nilai rtabel sebesar 0,2006, dapat dilihat pada lampiran. Berikut hasil uji validitas dapat dilihat sebagai berikut :

Tabel 2: Hasil Perhitungan Validitas Variabel penelitian

\begin{tabular}{|l|c|c|c|}
\hline Indikator & Rxy & Rtabel & Kriteria \\
\hline Kegunaan & 0.775 & 0.2006 & Valid \\
\hline Kemudahan & 0.868 & 0.2006 & Valid \\
\hline Resiko & 0.870 & 0.2006 & Valid \\
\hline Niat & 0.824 & 0.2006 & Valid \\
\hline
\end{tabular}

Sumber : Data diolah 2020

Pada tabel 2 diatas menunjukkan bahwa semua indikator yang digunakan untuk mengukur variabel-variabel pada penelitian ini memiliki koefisien korelasi ( $\mathrm{r}$ hitung) leih besar dari $\mathrm{r}$ tabel sebesar 0,2006 ( $\mathrm{df}=84-2=82)$. Dengan demikian semua indikator diatas adalah valid.

\subsection{Uji Reabilitas}

Uji reliabilitas adalah uji yang dipakai untuk menunjukkan sejauh mana suatu hasil pengukuran relatif konsisten apabila alat ukur yang digunakan berulang kali.. pengujian yang dipakai adalah dengan teori Cronbach Alpha. Suatu variabel dikatakan reliabel apabila memberikan nilai alpha $>0,60$. Hasil pengujian menggunakan program SPSS adalah sebagai berikut :

Tabel 3: Hasil Uji Reliabilitas

\begin{tabular}{|c|l|c|l|}
\hline No & \multicolumn{1}{|c|}{ Variabel } & $\begin{array}{c}\text { Cronbach's } \\
\text { Alpha }\end{array}$ & Kriteria \\
\hline 1 & Kegunaan & .788 & Reliabel \\
\hline 2 & Kemudahan & .810 & Reliabel \\
\hline 3 & Resiko & .783 & Reliabel \\
\hline 4 & Niat & .834 & Reliabel \\
\hline
\end{tabular}

Sumber : data diolah 2020 
Berdasarkan tabel diatas menunjukkan bahwa nilai Cronbach's Alpha instrument untuk semua variabel penelitian nilainya $>0,70$ sehingga dapat dikatakan bahwa instrument dalam penelitian ini adalah reliabel dan layak untuk digunakan.

Hasil penelitian menunjukkan bahwa Perceived Usefulness (Kegunaan), Perceived Ease of Use (kemudahan), Perceived Risk (resiko), dan Perceived Use Intention (niat) berpengaruh positif signifikan terhadap niat menggunakan EMoney. Dari berbagai informasi yang diperoleh dari penelitian ini, disebutkan bahwa niat masyarakat untuk menggunakan teknologi baru akan dipengaruhi oleh bagaimana suatu sistem atau teknologi yang akan diterapkan dapat digunakan dan membantu meningkatkan dan memfasilitasi penerapan teknologi baru.

Perceived Ease of Use (kemudahan berpengaruh positif signifikan terhadap niat menggunakan E-Money. Hasil ini sejalan dengan hasil penelitian sebelumnya Sehingga hasil penelitian ini memberikan gambaran sektor keuangan yang menggunakan Fintech untuk dapat memberikan layanan yang mudah bagi pengguna, dapat dipelajari dengan mudah, dan dapat meningkatkan proses transaksi.

Perceived Risk (resiko) berpengaruh positif signifikan terhadap niat menggunakan EMoney. Hal ini serupa dengan penulis sebelumnya seperti (Padmawidjaja et al., 2020). Oleh karena itu, dalam penelitian ini peneliti memaparkan bahwa tingkat keamanan atau risiko yang akan dihadapi ketika masyarakat menggunakan Fintech E-Money sebagai metode pembayaran memiliki tingkat signifikansi paling rendah di antara semua variabel yang peneliti gunakan. sehingga peneliti menyimpulkan bahwa risiko atau keamanan bukanlah pertimbangan terpenting bagi kepentingan masyarakat dalam menggunakan e-money.

\section{Conclusion}

Dari hasil di atas dapat disimpulkan bahwa variabel yang diteliti dalam penelitian ini memiliki pengaruh terhadap minat masyarakat dalam menggunakan uang elektronik sebagai alat pembayaran.

\section{References}

[1] Singh, R., \& Malik, G. (2019); "Impact of Digitalization on Indian Rural Banking Customer: With Reference to Payment Systems". Emerging Economy Studies, 5(1), page 31 - 41.

[2] Rumondang, A., Sudirman, A., Effendy, F., Simarmata, J., Agustin T., (2019); Fintech: Inovasi Sistem Keuangan di Era Digital. Google book

[3] Tarantang, J., Awwaliyah, A., Astuti, M., Munawaroh, M,. (2019); "Perkembangan Sistem Pembayaran Digital Pada Era Revolusi Industri 4.0 Di Indonesia”. Jurnal Al-Qardh IAIN Palangkaraya vol 4 no 1

[4] Nastiti Ninda Lintangsari, Nisaulfathona Hidayati, Yeni Purnamasari, Hilda Carolina, Wiangga Febranto (2018); "Analisis Pengaruh Instrumen Pembayaran Non-Tunai Terhadap Stabilitas Sistem Keuangan DI Indonesia". Jurnal Dinamika ekonomi Pembangunan, Academia.

[5] Eki Darmawan, (2018); "Perkembangan Smart City Kota Tanjungpinang". Jurnal Ilmu Pemerintahan vol 2 no 2 tahun 2018 hal 60-78.

[6] Muhammad Ramadhan, Nihayatu Aslamatis Solekah (2020); "Implementasi Transaksinon Tunai Pada Taman Rekreasi Selecta Kota Batu Jawa Timur". Jurnal Ekonomi dan Keuangan UKUITAS vol 4 no 1 tahun 2020 hal 67-86.

[7] Widayat, W., Masudin, I., \& Satiti, N. R. (2020). E-Money payment: Customers' adopting factors and the implication for open innovation. Journal of Open Innovation: Technology, Market, and Complexity, v0l 6 no. 3 tahun 2020.

[8] Amallia Ispriandina, Mamun Sutisna (2019). Faktor-faktor penerimaan teknologi yang memengaruhi intensi kontinuitas penggunaan mobile wallet di kota bandung. Prosiding Industrial Research Workshop and National Seminar Vol 10 No 1 (2019). 
[9] Endang Fatmawati (2015). Technology Acceptance Model (TAM) untuk Menganalisis Penerimaan terhadap Sistem Informasi di Perpustakaan. Iqra: Jurnal Perpustakaan dan Informasi Vol 9 No 1 (2015).

[10] Budi Santoso (2010). Pengaruh perceived usefulness, perceived ease of use, dan perceived enjoyment terhadap penerimaan teknologi informasi (Studi Empiris di Kabupaten Sragen). Jurnal Akuntansi dan Bisnis JAB Vol 10 no 2 (2010).

[11] Muhaji Bayu Suryawan, Prihandoko Prihandoko. (2017). Evaluasi Penerapan SIAKAD Politeknik Negeri Madiun Menggunakan Pendekatan TAM dan EUCS. Creative Information Technology Journal (Citec Journal) vol 4 no 3 tahun 2017 